\title{
The juice of fresh leaves of Catharanthus roseus Linn. reduces blood glucose in normal and alloxan diabetic rabbits Srinivas Nammi ${ }^{* 1}$, Murthy K Boini ${ }^{1}$, Srinivas D Lodagala ${ }^{1}$ and Ravindra Babu S Behara ${ }^{2}$
}

Address: ${ }^{1}$ Pharmacology Division, Department of Pharmaceutical Sciences Andhra University, Visakhapatnam-530 003, Andhra Pradesh, INDIA
and ${ }^{2}$ Current address: A15, Faculty of Pharmacy, University of Sydney, Sydney, NSW-2006 AUSTRALIA

Email: Srinivas Nammi* - nammi@rediffmail.com; Murthy K Boini - krishnamurthyboini@yahoo.com; Srinivas D Lodagala - Idsrinivas@rediffmail.com; Ravindra Babu S Behara - bsrbabu@hotmail.com

* Corresponding author

Published: 02 September 2003

BMC Complementary and Alternative Medicine 2003, 3:4
Received: 28 March 2003

Accepted: 02 September 2003

This article is available from: http://www.biomedcentral.com/1472-6882/3/4

(C) 2003 Nammi et al; licensee BioMed Central Ltd. This is an Open Access article: verbatim copying and redistribution of this article are permitted in all media for any purpose, provided this notice is preserved along with the article's original URL.

\begin{abstract}
Background: The leaf juice or water decoction of Catharanthus roseus L. (Apocyanaceae) is used as a folk medicine for the treatment of diabetes all over the world. In the present investigation, the leaf juice of $C$. roseus has been evaluated for its hypoglycemic activity in normal and alloxan-induced diabetic rabbits.

Methods: The blood glucose lowering activity of the leaf juice was studied in normal and alloxaninduced $(100 \mathrm{mg} / \mathrm{kg}$, i.v.) diabetic rabbits, after oral administration at doses of $0.5,0.75$ and $1.0 \mathrm{ml} /$ $\mathrm{kg}$ body weight. Blood samples were collected from the marginal ear vein before and also at 4, 6 , $8,10,12,16,18,20 \& 24 \mathrm{~h}$ after drug administration and blood glucose was analyzed by NelsonSomogyi's method using a visible spectrophotometer. The data was compared statistically by using Student's t-test.
\end{abstract}

Results: The leaf juice of $C$. roseus produced dose-dependent reduction in blood glucose of both normal and diabetic rabbits and comparable with that of the standard drug, glibenclamide. The results indicate a prolonged action in reduction of blood glucose by $C$. roseus and the mode of action of the active compound(s) of $C$. roseus is probably mediated through enhance secretion of insulin from the $\beta$-cells of Langerhans or through extrapancreatic mechanism.

Conclusions: The present study clearly indicated a significant antidiabetic activity with the leaf juice of Catharanthus roseus and supports the traditional usage of the fresh leaves by Ayurvedic physicians for the control of diabetes.

\section{Background}

Diabetes mellitus is a major endocrine disorder affecting nearly $10 \%$ of the population all over the World [1]. Inspite of the introduction of hypoglycemic agents, diabetes and the related complications continue to be a major medical problem. Since time immemorial, patients with non-insulin dependent diabetes mellitus have been treated orally by folklore with a variety of plant extracts. In the indigenous Indian system of medicine (Ayurveda), a mention was made on good number of plants for the cure of diabetes or 'madhumeha' and some of them have been experimentally evaluated and the active principles were isolated [2-8]. However, search for new antidiabetic drugs continues. 
Catharanthus roseus (L.) G. Don (Apocyanaceae) is known with various names (Madagascar periwinkle; Vinca rosea; Lochnera rosea) in India and all over the world. Water decoction of the leaves and/or the whole plant is used as household remedy for diabetes in several countries [9]. Traditionally, in India seven flowers/leaves are used at a time whereas in the Cook Islands 18 leaves boiled in a kettle of water and in West Indies roots of plants infused in whiskey are used to control diabetes [10-12]. Earlier reports indicate significant blood glucose lowering activity with hydroalcoholic or dichloromethane-methanol extracts of leaves of $C$. roseus in laboratory animals [1319]. The use of fresh leaf juice of $C$. roseus has been in practice by Ayurvedic physicians in India with beneficial action. Hence, in the present study the leaf juice of $C$. roseus has been evaluated for hypoglycemic activity in normal and alloxan diabetic rabbits.

\section{Methods}

\section{Plant material}

Fresh leaves of $C$. roseus (white variety) were collected from our University campus and were crushed in a stainless steel mortar and squeezed by means of a fine cloth to separate the juice. The authenticity of the plant was done by botanist Dr. M. Venkaiah, Department of Botany, Andhra University and the voucher specimen was kept in the herbarium (No. 0614) of our University.

\section{Chemicals Used}

Glibenclamide was provided as a generous gift sample by Hoechst Pharmaceuticals, Mumbai, while alloxan (Sigma Chemical Company, USA) was a generous gift sample from Dr. Reddy's Laboratories, Hyderabad. All other reagents used were of analytical grade.

\section{Animal Experiments}

Adult albino rabbits (B.N. Ghosh \& Co., Kolkata) of either sex weighing $1.5-2 \mathrm{~kg}$ were used in the study. They were divided into 10 groups of five each and were provided with a standard diet and water ad libitum. All the rabbits were kept in cages with wide square mesh at the bottom to avoid coprophagy and maintained in a well-ventilated animal house with $12 \mathrm{~h}$ light and dark cycle. They were fasted for $18 \mathrm{~h}$ prior to the experiment, allowing access to water only, and were deprived of both food and water during the $24 \mathrm{~h}$ monitoring period of the experiment after the treatment either with the drug or distilled water (control) to minimize the changes in plasma volume. The same procedure has been followed for each treatment. The experimental protocol has been approved by the Institutional Animal Ethics Committee and by the animal regulatory body of the government (Regd. No. 516/01/A/ CPCSEA)
Groups I to IV consist of normal animals, as well as the normal control, group V. Groups I, II \& III were given the leaf juice of $C$. roseus orally through intragastric intubation at doses of $0.5,0.75$ and $1.0 \mathrm{ml} / \mathrm{kg}$ body weight respectively. The gastric tube was washed with distilled water after drug administration, such that each animal received a total volume of $3 \mathrm{ml}$. Group IV was given glibenclamide at a dose of $40 \mu \mathrm{g} / \mathrm{kg}$ orally in a total volume of $3 \mathrm{ml}$ for each animal. Group V, the normal control received $3 \mathrm{ml}$ of distilled water.

Groups VI to X were rendered diabetic by injecting alloxan $(100 \mathrm{mg} / \mathrm{kg}, \mathrm{i} . \mathrm{v})$ into the marginal ear vein after a base line blood glucose $(95.3,99.7,105.1,91.0$ and $101.3 \mathrm{mg} /$ dl respectively) estimation was done. After two weeks when the condition of diabetes was stabilized, rabbits with blood glucose above $300 \mathrm{mg} / \mathrm{dl}$ were selected for the study.

Animals in groups VI, VII \& VIII received the leaf juice of C. roseus orally at doses of $0.5,0.75$ and $1.0 \mathrm{ml} / \mathrm{kg}$ respectively. Group IX received glibenclamide orally at a dose of $40 \mu \mathrm{g} / \mathrm{kg}$. Group X served as diabetic control.

\section{Collection of blood and analytical procedure}

Blood samples (approx. $0.3 \mathrm{ml}$ ) were collected by puncturing the marginal ear vein of each rabbit of a group before and also at 4, 6, 8, 10, 12, 16, 18, 20 \& 24 h after oral administration of the drug. The samples were collected into glass vials containing a small quantity of a mixture of potassium oxalate and sodium fluoride as anticoagulant. They were stored at $4^{\circ} \mathrm{C}$ in a refrigerator before the analysis of glucose by Nelson-Somogyi's method [2022] using a visible spectrophotometer.

\section{Data and Statistical Analysis}

Data was expressed as mean \pm standard error of means. Statistical analysis was made by using Student's unpaired $t$-test.

\section{Results}

The leaf juice of $C$. roseus produced a dose-dependent hypoglycemia in normal rabbits. It produced maximum reduction in blood glucose of $16.7 \%$ ( $6 \mathrm{~h}, \mathrm{p}<0.05)$, $28.6 \%$ (18 h, p < 0.05), and 31.9\% (20 h, p < 0.01) with doses of $0.5,0.75$ and $1.0 \mathrm{ml} / \mathrm{kg}$ body weight respectively (Table 1$)$. Glibenclamide $(40 \mu \mathrm{g} / \mathrm{kg})$ produced a significant $(\mathrm{p}<0.01)$ reduction in blood glucose compared to control $(31.9 \%, 8 \mathrm{~h})$.

Dose-dependent reduction in blood glucose was also observed in alloxan-induced diabetic rabbits treated with C. roseus. The percent reduction in blood glucose tended to be higher in the diabetic condition compared to the normal state. A significant reduction $(\mathrm{p}<0.001)$ in blood 
Table I: Percentage blood glucose reduction produced by $C$. roseus after oral administration in normal rabbits.

\begin{tabular}{|c|c|c|c|c|c|c|c|c|c|c|c|}
\hline \multirow{2}{*}{$\begin{array}{l}\text { Group } \\
(n=5)\end{array}$} & \multirow[t]{2}{*}{ Dose } & \multirow{2}{*}{$\begin{array}{l}\text { Initial } \\
\text { Blood } \\
\text { glucose } \\
(\mathrm{mg} / \mathrm{dl})\end{array}$} & \multicolumn{9}{|c|}{ Percent blood glucose reduction } \\
\hline & & & 4 & 6 & 8 & 10 & 12 & 16 & 18 & 20 & 24 (h) \\
\hline Control & --- & 105.6 & $-3.1 \pm 5.3$ & $-2.4 \pm 6.4$ & $-0.4 \pm 6.2$ & $-3.6 \pm 5.0$ & $-6.9 \pm 6.3$ & $-4.5 \pm 4.2$ & $-0.4 \pm 9.9$ & $5.9 \pm 1.5$ & $-1.5 \pm 4.6$ \\
\hline C. roseus & $0.50 \mathrm{ml} / \mathrm{kg}$ & 99.2 & $11.5 \pm 0.7^{*}$ & $16.7 \pm 1.2^{*}$ & $15.3 \pm 3.1$ & $12.6 \pm 2.4^{*}$ & $4.9 \pm 8.0$ & $4.6 \pm 6.6$ & $8.1 \pm 2.1$ & $8.9 \pm 1.9$ & $1.0 \pm 4.4$ \\
\hline C. roseus & $0.75 \mathrm{ml} / \mathrm{kg}$ & 101.4 & $13.9 \pm 5.1^{*}$ & $17.1 \pm 1.9 *$ & $19.5 \pm 3.4^{*}$ & $19.7 \pm 5.7^{*}$ & $22.8 \pm 3.1^{\text {*⿰冫⿰㇇⿰亅⿱丿丶丶 }}$ & $27.0 \pm 0.7^{* * * *}$ & $28.6 \pm 0.4^{*}$ & $14.7 \pm 6.2$ & $4.3 \pm 7.1$ \\
\hline C. roseus & $1.0 \mathrm{ml} / \mathrm{kg}$ & 108.5 & $\mid 4.1 \pm 3.3^{*}$ & $17.5 \pm 3.2^{*}$ & $19.2 \pm 2.6^{*}$ & $20.8 \pm 6.1^{*}$ & $24.4 \pm 4.4^{\text {** }}$ & $29.6 \pm 4.2^{* * * * *}$ & $30.7 \pm 5.2^{*}$ & $31.9 \pm 5.3^{* *}$ & $30.0 \pm 1.4^{* * * k}$ \\
\hline Glibenclamide & $40 \mu \mathrm{g} / \mathrm{kg}$ & 104.2 & $25.5 \pm 4 . I^{* * *}$ & $29.7 \pm 4.9 * *$ & $31.9 \pm 4.8^{* *}$ & $29.8 \pm 5.2^{* * *}$ & $28.3 \pm 4.7^{* *}$ & $23.1 \pm 3.6$ ** & $21.9 \pm 3.6$ & $19.8 \pm 5.4$ & $17.3 \pm 4.7$ \\
\hline
\end{tabular}

Values are mean percent blood glucose reduction ( \pm S.E.M.) of five animals. Significant difference from control at corresponding intervals: ${ }^{*} p<0.05$, $*_{p}<0.01$, ***p $<0.001$

Table 2: Percentage blood glucose reduction produced by C. roseus after oral administration in alloxan-induced diabetic rabbits.

\begin{tabular}{|c|c|c|c|c|c|c|c|c|c|c|c|}
\hline \multirow{2}{*}{$\begin{array}{l}\text { Group } \\
(n=5)\end{array}$} & \multirow[t]{2}{*}{ Dose } & \multirow{2}{*}{$\begin{array}{l}\text { Initial } \\
\text { Blood } \\
\text { glucose } \\
\text { (mg/dl) }\end{array}$} & \multicolumn{9}{|c|}{ Percent blood glucose reduction } \\
\hline & & & 4 & 6 & 8 & 10 & 12 & 16 & 18 & 20 & 24 (h) \\
\hline Control & --- & 324.7 & $1.2 \pm 0.3$ & $0.7 \pm 0.3$ & $0.1 \pm 0.3$ & $-0.5 \pm 0.4$ & $-0.5 \pm 0.2$ & $0.2 \pm 0.5$ & $-0.6 \pm 1.9$ & $-0.7 \pm 0.1$ & $-0.2 \pm 0.3$ \\
\hline C. roseus & $0.50 \mathrm{ml} / \mathrm{kg}$ & 316.0 & $10.5 \pm 1.9 * *$ & $14.9 \pm 0.8^{* * * *}$ & $19.6 \pm 0.5^{* * * *}$ & $16.85 \pm 0.8^{* * *}$ & $13.4 \pm 4.9 * *$ & $8.9 \pm 1.9^{* *}$ & $7.7 \pm 2.4^{*}$ & $6.3 \pm 1.3 * * *$ & $4.4 \pm 1.6^{*}$ \\
\hline C. roseus & $0.75 \mathrm{ml} / \mathrm{kg}$ & 304.9 & $14.6 \pm 4.5^{*}$ & $16.7 \pm 2.5^{* * * *}$ & $22.2 \pm 3.8^{* * * *}$ & $24.5 \pm 7.4^{* *}$ & $27.8 \pm 6.5 * *$ & $27.4 \pm 3.5 * * * *$ & $31.4 \pm 5.6 * * * *$ & $25.8 \pm 5.1^{* * * *}$ & $19.4 \pm 6.4^{*}$ \\
\hline C. roseus & $1.0 \mathrm{ml} / \mathrm{kg}$ & 319.2 & $16.8 \pm 5.8^{*}$ & $20.9 \pm 5.5^{* *}$ & $24.1 \pm 2.9 * * * *$ & $26.6 \pm 4.9^{* * * * *}$ & $27.5 \pm 9.2^{*}$ & $30.4 \pm 6.9^{*}$ & $32.7 \pm 6.0 * * * *$ & $36.5 \pm 4.8^{* * * *}$ & $31.8 \pm 8.5^{* *}$ \\
\hline Glibenclamide & $40 \mu g / \mathrm{kg}$ & 323.9 & $\begin{array}{l}22.6 \pm \\
3.6 * * * *\end{array}$ & $28.5 \pm 5.5^{* * * *}$ & $34.9 \pm 4.6 * * *$ & $28.7 \pm 6.5^{* *}$ & $24.8 \pm 5.7 * *$ & $24.6 \pm 4.1 * * * *$ & $21.3 \pm 5.6$ ** & $17.4 \pm 9.8$ & $14.5 \pm 5.9 *$ \\
\hline
\end{tabular}

Values are mean percent blood glucose reduction ( \pm S.E.M.) of five animals. Significant difference from control at corresponding intervals: ${ }^{*} \mathrm{p}<0.05$, $* * p<0.01, * * * p<0.001$

glucose of $19.6 \%(8 \mathrm{~h}), 31.4 \%(18 \mathrm{~h})$ and $36.5 \%(20 \mathrm{~h})$ was observed with $C$. roseus at doses of $0.5,0.75$ and 1.0 $\mathrm{ml} / \mathrm{kg}$ body weight respectively (Table 2 ). Glibenclamide $(40 \mu \mathrm{g} / \mathrm{kg})$ produced a significant reduction $(\mathrm{p}<0.001)$ in blood glucose compared to diabetic control at the $8 \mathrm{~h}$ (34.9\%).

\section{Discussion}

Diabetes mellitus is possibly the world's largest growing metabolic disease, and as the knowledge on the heterogeneity of this disorder is advanced, the need for more appropriate therapy increases [23]. Traditional plant medicines are used throughout the world for a range of diabetic complications. The study of such medicines might offer a natural key to unlock a diabetologist's pharmacy for the future.

Leaves and flowers of $C$. roseus are used traditionally by diabetic patients in India and are taken as water decoction. Due to this reason the leaf juice of the plant was evaluated and the data also confirmed the traditional indications. Earlier investigations [13-19] on the antidiabetic activity of the organic extracts of $C$. roseus by various authors also substantiate the results of our studies in rabbits. Moreover, the fact that the juice has a more prolonged effect (at $1.0 \mathrm{ml} / \mathrm{kg}$ ) than the glibenclamide dose in the period $18-24 \mathrm{~h}$ after treatment indicates a prolonged duration of antidiabetic action and could be due to multiple sites of action possessed by the active principles of C. roseus.

Alloxan, a beta-cytotoxin causes a massive destruction of $\beta$-cells of the islets of Langerhans resulting in reduced synthesis and release of insulin [24-26]. It is well established that sulphonylureas produce hypoglycemia by increasing the secretion of insulin from pancreas and these compounds are active in mild alloxan-induced diabetes whereas they are inactive in intense alloxan diabetes (nearly all $\beta$-cells have been destroyed) $[27,28]$. Since our results showed that glibenclamide reduced blood glucose levels in hyperglycemic animals, the state of diabetes is not severe. Alloxan-treated animals receiving the leaf juice of $C$. roseus showed rapid normalization of blood glucose levels in comparison to control and this could be due to the possibility that some $\beta$-cells are still surviving to act upon by C. roseus to exert its insulin releasing effect. More- 
over, like sulphonylureas oral administration of C. roseus produced hypoglycemia in normal animals. This suggests that the mode of action of the active ingredients of $C$. roseus is probably mediated by an enhanced secretion of insulin, like sulphonylureas. However, the possibility that enhanced tissue glucose utilization by $C$. roseus cannot be ruled out. Further work is obviously required to fractionate, purify and identify the active aqueous principle(s) present in the leaves of Catharanthus roseus.

\section{Conclusions}

Our study clearly indicated a significant antidiabetic activity with the leaf juice of Catharanthus roseus and supports the traditional usage of fresh leaves by the Ayurvedic physicians for the control of diabetes. Hence it might help in preventing diabetic complications and serve as a good adjuvant in the present armamentarium of antidiabetic drugs.

\section{References}

I. Burke JP, Williams K, Narayan KMV, Leibson C, Haffner SM and Stern MP: A population perspective on diabetes prevention: whom should we target for preventing weight gain? Diabetes Care 2003, 26:1999-2004.

2. Chopra RN, Nayar SL and Chopra IC: Glossary of Indian Medicinal Plants,. New Delhi, CSIR 1956.

3. Al-Awadi FM and Gumaa KA: Studies on the activity of individual plants of an antidiabetic plant mixture. Acta Diabetologica Latina 1987, 24:37-4I.

4. Ivorra MD, Paya M and Villar A: A review of natural products and plants as potential antidiabetic drugs. J Ethnopharmacol 1989, 27:243-75.

5. Alarcon-Aguilara F], Roman-Ramos R, Perez-Gutierrez S, AguilarContreras A, Contreras-Webar CC and Flores-Saenz JL: Study of the anti-hyperglycemic effect of plants used as antidiabetics. J Ethnopharmacol |998, 6 I:101-10.

6. Chattopadhyay RR: A comparative evaluation of some blood glucose lowering agents of plant origin. J Ethnopharmacol 1999, 67:367-72.

7. Ajit K, Choudhary BK and Bandhopadhyay NG: Preliminary studies on the inorganic constituents of some indigenous hypoglycemic herbs on oral glucose tolerance test. J Ethnopharmacol 1999, 64:179-84.

8. Grover JK, Yadav S and Vats V: Medicinal plants of India with antidiabetic potential. J Ethnopharmacol 2002, 8I:8I-100.

9. Don G: Catharanthus roseus. In: Medicinal Plants of the World Edited by: Ross IA. Totowa, New Jersey, Human Press; 1999:109-18.

10. Cowley RC and Bennett FC: Vinca rosea. Australation J Pharm 1928, 9:61.

II. Kirtikar KR and Basu BD: Vinca rosea. In: Indian Medicinal Plants (II ed.) Allahabad, India, Lalit Mohan Basu Publications 1933, Vol III: $1559-60$.

12. Sastry BN: The wealth of India. New Delhi, CSIR, Publication and Information Directorate 1953:205.

13. Pillay PP, Nair CPM and Santi Kumari TN: Lochnera rosea as a potential source of hypotensive and other remedies. Bull Research Inst Univ Kerala, Ser. A6 1959, 1:5 I-4.

14. Gordon SH, Marvin G and Marry RA: Alkaloids of Vinca rosea : A preliminary report on hypoglycemic activity. Lloydia 1964, 27:36I-63.

15. Stolle $\mathrm{K}$ and Greoger D: Catharanthus roseus - a new medicinal plant. Pharm Zentralh Deut 1967, 106:285-306.

16. Ghosh RK and Gupta I: Effect of Vinca rosea and Ficus racemososus on hyperglycemia in rats. Ind J Animal Health 1980, 19:145-48.

17. Swanston-Flatt SK, Day C, Flatt PR, Gould BJ and Bailey CJ: Glycaemic effects of traditional European plant treatments for diabetes. Studies in normal and streptozotocin diabetic mice. Diabetes Res 1989, 10:69-73.
18. Chattopadhyay RR, Sarkar SK, Ganguli S, Banerjee RN and Basu TK: Hypoglycemic and antihyperglycemic effect of leaves of Vinca rosea Linn. Ind J Physiol Pharmacol I991, 35: 145-5I.

19. Singh SN, Vats P, Suri S, Shyam R, Kumria MML, Ranganathan $S$ and Sridharan K: Effect of an antidiabetic extract of Catharanthus roseus on enzymic activities in streptozotocin induced diabetic rats. J Ethnopharmacol 200I, 76:269-77.

20. Nelson N: A photometric adaptation of the Somogyi's method for the determination of glucose. J Biol Chem 1944 , 153:375-80

21. Somogyi N: A new reagent for the determination of sugars. J Biol Chem 1945, 160:61-75.

22. Hawk PB and Bernard LO: Practical Physiological Chemistry. New York, McGraw Hill Co XIIII 1954:573-75.

23. Baily Cl and Flatt PR: Antidiabetic drugs, new developments. Ind Biotech 1986, 6: 139-42.

24. Lazarow A: Alloxan diabetes and mechanism of $\beta$-cell damage by chemical agents. In: Experimental Diabetes Edited by: Lazarow A. Oxford, Blackwell Scientific Publication; 1964:49-69.

25. Rerup CC: Drugs producing diabetes through damage of insulin secreting cells. Pharmacol Rev 1970, 22:485-520.

26. Colca JR, Kotagel N, Brooks CL, Lacy PE, Landt M and McDanield ML: Alloxan inhibition of $\mathrm{Ca}^{2+}$ and calmodulin-dependent protein kinase in pancreatic islets. J Biol Chem 1983, 225:7260-63.

27. Yallow RS, Black $H$, Villazan $M$ and Berson SA: Comparison of plasma insulin levels following administration of tolbutamide and glucose. Diabetes 1960, 9:356-62.

28. Grodsky GM, Epstein GH, Fanska R and Karam JH: Pancreatic action of sulphonylureas. Fed Proc 197I, 36:27I9-28.

\section{Pre-publication history}

The pre-publication history for this paper can be accessed here:

http://www.biomedcentral.com/1472-6882/3/4/prepub
Publish with Biomed Central and every scientist can read your work free of charge

"BioMed Central will be the most significant development for disseminating the results of biomedical research in our lifetime. "

Sir Paul Nurse, Cancer Research UK

Your research papers will be:

- available free of charge to the entire biomedical community

- peer reviewed and published immediately upon acceptance

- cited in PubMed and archived on PubMed Central

- yours - you keep the copyright
BioMedcentral 